\title{
Helicobacter pylori Infection: Comparison of Knowledge between Health Science and Non-Health Science University Students
}

\author{
Taghreed A. Hafiz ${ }^{1, *}$, Juliana Linnette D'Sa ${ }^{2} \mathbb{D}$, Sahar Zamzam ${ }^{2,3}$, Maria Liza Visbal Dionaldo ${ }^{4}$, \\ Murad A. Mubaraki ${ }^{1}$ and Regie Buenafe Tumala ${ }^{5}$ \\ 1 Clinical Laboratory Sciences Department, College of Applied Medical Sciences, King Saud University, \\ Riyadh 12372, Saudi Arabia; mmubaraki@KSU.EDU.SA \\ 2 Maternal and Child Health Nursing Department, College of Nursing, King Saud University, \\ Riyadh 12372, Saudi Arabia; jdsa@KSU.EDU.SA (J.L.D.); szamzam@KSU.EDU.SA (S.Z.) \\ 3 Obstetric and Gynaecologic Nursing Department, Alexandria University, Alexandria 21544, Egypt \\ 4 Metro Technology Centers, Oklahoma City, OK 73111, USA; marializa.dionaldo@gmail.com \\ 5 Medical-Surgical Nursing Department, College of Nursing, King Saud University, \\ Riyadh 12372, Saudi Arabia; rtumala@KSU.EDU.SA \\ * Correspondence: thafiz@ksu.edu.sa
}

check for updates

Citation: Hafiz, T.A.; D'Sa, J.L.; Zamzam, S.; Dionaldo, M.L.V.; Mubaraki, M.A.; Tumala, R.B. Helicobacter pylori Infection:

Comparison of Knowledge between Health Science and Non-Health Science University Students. Int. J. Environ. Res. Public Health 2021, 18, 8173. https://doi.org/10.3390/ ijerph18158173

Academic Editor: Paul B. Tchounwou

Received: 1 July 2021

Accepted: 28 July 2021

Published: 2 August 2021

Publisher's Note: MDPI stays neutral with regard to jurisdictional claims in published maps and institutional affiliations.

Copyright: (c) 2021 by the authors Licensee MDPI, Basel, Switzerland. This article is an open access article distributed under the terms and conditions of the Creative Commons Attribution (CC BY) license (https:/ / creativecommons.org/licenses/by/ $4.0 /)$.

\begin{abstract}
Background: Helicobacter pylori (H. pylori), an important human pathogen, is classified as a human carcinogen. It is known to cause dyspepsia, peptic ulcers, and gastric cancer. Awareness regarding H. pylori infections in Saudi Arabia awaits investigation to reduce or even eliminate the infection that would ease the substantial burden of managing $H$. pylori among both malignant and non-malignant diseases. Aims: The study aims were to (1) assess the knowledge of $H$. pylori infection, testing, and management among undergraduate students in Saudi Arabia and (2) compare the H. pylori knowledge among health science and non-health science students. Methods: This study involved a cross-sectional online survey among 334 undergraduate students in health science and non-health science colleges at King Saud University, Saudi Arabia, using a valid and reliable authordeveloped survey. The survey had two sections: the socio-demographic factors and knowledge items regarding H. pylori. Data were collected during the 2019-2020 academic year. Data analysis included descriptive statistics, Chi-square, and Mann-Whitney U test. The knowledge scores were categorized as poor, fair, and good. Results: Less than $10 \%$ of the students in both groups had a good knowledge level about $H$. pylori. The comparison of the overall mean between both groups was non-significant. Moreover, the level of knowledge of the respondents was significantly associated with their university level ( $p<0.001)$, family monthly income $(p<0.007)$, having heard about H. pylori infection $(p<000.1)$, and a previous history of $H$. pylori infection $(p<000.1)$. Conclusion: The overall knowledge level of Saudi undergraduate students about $H$. pylori infection was low. Thus, health awareness interventions through educational programs are recommended for improving their knowledge about $H$. pylori infection and its prevention.
\end{abstract}

Keywords: awareness; infectious disease; H. pylori infection; knowledge; undergraduate student; infection control; gastric cancer

\section{Introduction}

Helicobacter pylori (H. pylori) are human pathogens transmitted from human to human through oral routes and cause chronic gastritis in all colonized subjects [1]. This gramnegative bacterium is a common infectious pathogen that inhabits the gastric mucosa in around $40-50 \%$ of the world's population, leading to a global public health issue. The incidence of infection varies geographically and is over 75\% in Portugal, Turkey and Kazakhstan, and some African countries [1,2]. In the Riyadh region of Saudi Arabia, Alghamdi et al. [3] reported an incidence of 34.7\%. Furthermore, a recent review that 
included published literature from Saudi Arabia reported a prevalence ranging from $27-66 \%$ in the Middle East and North Africa region [4]. The high incidence and prevalence of $H$. pylori infection is a public health concern.

Evidence shows that $H$. pylori infection is associated with gastric cancer [5], the third leading cancer-related death and the fifth most common cancer worldwide [6]. It is also established that $H$. pylori is primarily related to the development of gastroduodenal disorders and, more commonly, chronic gastritis, peptic ulcers, and gastric adenocarcinoma, or lymphomas $[7,8]$. H. pylori gastritis is designated as an infectious disease in the Maastricht $\mathrm{V} /$ Florence consensus report [9]. The infection caused by H. pylori may either be asymptomatic and/or symptomatic. Epigastric pain, upper abdominal discomfort, indigestion, nausea, loss of appetite, reflux, and/or belching are among the most frequently occurring symptoms.

Commonly transmitted through oral routes, the fecal-oral, oral-oral, and gastro-oral routes, the definite interpersonal mode of transmission is still unknown [10,11]. However, several demographic factors are associated with the H. pylori infection. High income and higher educational levels are associated with a decrease in the prevalence of $\mathrm{H}$. pylori gastritis [12,13]. Additionally, age, occupation, the type of drinking water used, consumption of fruits, vegetables, or fried food are also independent risk factors for $\mathrm{H}$. pylori infection [14-16]. Smoking and alcohol consumption were also found to be independently positively associated factors [17]. Many of these risk factors are preventable with adequate knowledge and appropriate practice. There appears to be limited knowledge about $H$. pylori among the general population, primarily related to transmission. Evidence shows low awareness of H. pylori infection in Canada [18], the United States [19], China [20-22], and South Korea $[23,24]$. Knowledge about screening and prevention among risk groups, early diagnosis, and treatment may prompt people to seek measures to prevent the infection $[9,24]$. It is essential to educate the general population, especially the university students who are a segment of the general population.

There is a paucity of studies on H. pylori among university students who may be vulnerable to the infection. Therefore, assessing their awareness regarding $H$. pylori will form a basis for developing educational content that can enhance their knowledge and improve screening practices among those at risk. A comparison between health science and non-health science students will provide an understanding of the depth of knowledge they possess from their courses. To our knowledge, this is the first study that compares the knowledge about $H$. pylori infection, testing, and management among health science and non-health science undergraduate students in Saudi Arabia.

\section{Methods}

\subsection{Study Design and Setting and Participants}

This cross-sectional descriptive comparative study, a part of a large study, was designed to compare the knowledge of health science and non-health science undergraduate students regarding H. pylori in King Saud University, Riyadh, Saudi Arabia. Two health science colleges: College of Applied Medical Science and College of Nursing, and two nonhealth science colleges: College of Science and College of Computer Science were selected conveniently based on the accessibility of the researchers. The sample size calculated, using Raosoft, Inc., with 95\% confidence and assuming an error of 5\%, was 255. Compensating for nonresponse, 334 undergraduate students were selected. They were included if they had registered for the full-time baccalaureate program during the 2019-2020 academic year and consented to participate. Students enrolled in the common preparatory year were excluded.

\subsection{Data Collection}

Data were collected over six months, from September 2019 to February 2020, using a structured online survey on knowledge of H. pylori, developed by the authors. Six content experts validated the draft survey. Minor modifications were made as per their suggestions. 
The CVI index of the instrument was 0.915 , ascertaining the validity of the questions. The final instrument had two sections: The first section assessed the socio-demographic factors, and the second section measured knowledge regarding H. pylori through 14 singleresponse multiple-choice items. The content areas of the survey were "meaning/perception of $H$. pylori infection and complications" (three items; items 1, 13, and 14), "signs and symptoms and risk factors" (four items; items 2-5), "mode of spread and prevention" (two items; items 6 and 8), "diagnosis, treatment, and self-care" (five items; items 7, 9-12). Each correct response was awarded a score of 1, with a total maximum possible score of 14 . The knowledge scores were classified into three levels, based on the percentage of scores obtained by the participants: good $(>75 \%)$, fair $(50-75 \%)$, and poor $(<50 \%)$. The questionnaire had excellent reliability (alpha $=0.949)$.

\subsection{Procedure for Data Collection}

After seeking ethical approval, the web link to the knowledge questionnaire, prepared using Google forms, was sent to the Questionnaire Centre of the University, which sent the invitation to the registered email of the students. The students were aware of the study's purpose and that the data would be used only for research purposes. Participation was voluntary and responding to the questionnaire implied consent. Once the students clicked on the web link, they would view the information about the purpose of the study and the implied consent and would proceed by responding to the demographic items and the knowledge questions before clicking on the "submit" button. On average, participants completed the questionnaire in 15-20 min.

\subsection{Ethical Consideration}

The study received ethical approval from the Institutional Review Board, King Saud University (Ref. No. 21/0111/IRB). All data were kept confidential and were available only to the research team.

\subsection{Statistical Analysis}

The data were analyzed using the Statistical Package for Social Sciences (SPSS) version 20 (Armonk, NY, USA) for IBM. Frequency and percentage were computed to quantify the socio-demographic data and the responses of the participants on the individual knowledge items. The knowledge scores were categorized as poor, fair, and good, based on the percentage of scores obtained. The Mann-Whitney $U$ test was used to find the difference in the knowledge scores in the two groups, and Chi-square was computed to find the relationship between the socio-demographic variables and the knowledge scores.

\section{Results}

\subsection{Socio-Demographic Characteristics of the Respondents}

The majority of the respondents were females (55.7\%), in the age group 20 to $<30$ years $(63.2 \%)$. Most of the respondents were enrolled in health science colleges $(56.6 \%)$, with the highest proportion in the second year (fourth level) of study (44\%). Most of them (56\%) had 4-7 siblings. Almost two-thirds (64.1\%) indicated having a monthly family income of more than 10,000 Saudi riyals ( $1 \mathrm{USD}=3.77 \mathrm{SR}$ ).

With regards to the respondents' habits, 309 (92.5\%) reported drinking coffee or tea. Out of the 309, the majority (53.7\%) indicated consuming 2-5 cups of coffee or tea per day. More than half of the respondents $(59.9 \%)$ reported having bottled water as their source of drinking water. When asked if they knew H. pylori is a microbe that causes peptic ulcers, the majority answered correctly $(76.9 \%)$ and most responded that they acquired the information from reading articles $(62.3 \%)$. Only 60 respondents $(18.0 \%)$ reported having a previous history of $H$. pylori infection, and out of the $60,50(90.0 \%)$ reported that it was treated (Table 1). 
Table 1. Socio-demographic characteristics of the respondents $(n=334)$.

\begin{tabular}{|c|c|c|c|c|c|c|}
\hline \multirow{2}{*}{ Items } & \multicolumn{2}{|c|}{$\begin{array}{l}\text { Total Sample } \\
\quad(n=334)\end{array}$} & \multicolumn{2}{|c|}{$\begin{array}{l}\text { Health Science } \\
\quad(n=189)\end{array}$} & \multicolumn{2}{|c|}{$\begin{array}{c}\text { Non-Health Science } \\
(n=145)\end{array}$} \\
\hline & $n$ & $\%$ & $n$ & $\%$ & $n$ & $\%$ \\
\hline \multicolumn{7}{|l|}{ Age (Years) } \\
\hline$<20$ & 94 & 28.1 & 52 & 27.5 & 42 & 29.0 \\
\hline $20-30$ & 211 & 63.2 & 116 & 61.4 & 95 & 65.5 \\
\hline$\geq 30$ & 29 & 8.7 & 21 & 11.1 & 8 & 5.5 \\
\hline \multicolumn{7}{|l|}{ Gender } \\
\hline Male & 148 & 44.3 & 68 & 36.0 & 80 & 55.2 \\
\hline Female & 186 & 55.7 & 121 & 64.0 & 65 & 44.8 \\
\hline \multicolumn{7}{|l|}{ Field of study in the university } \\
\hline Health colleges & 189 & 56.6 & 189 & 56.6 & - & - \\
\hline Applied Medical Sciences & 132 & 39.5 & 132 & 39.5 & - & - \\
\hline Nursing & 57 & 17.1 & 57 & 17.1 & - & - \\
\hline Non-Health colleges & 145 & 43.4 & - & - & 145 & 43.4 \\
\hline Sciences & 80 & 24.0 & - & - & 80 & 24.0 \\
\hline Computer Sciences & 65 & 19.5 & - & - & 65 & 19.5 \\
\hline \multicolumn{7}{|l|}{ University level } \\
\hline Level 4 (Year II, Semester 2) & 147 & 44.0 & 83 & 43.9 & 64 & 44.1 \\
\hline Level 5 (Year III, Semester 1) & 38 & 11.4 & 24 & 12.7 & 14 & 9.7 \\
\hline Level 6 (Year III, Semester 2) & 50 & 15.0 & 23 & 12.2 & 27 & 18.6 \\
\hline Level 7 (Year IV, Semester 1) & 22 & 6.6 & 16 & 8.5 & 6 & 4.1 \\
\hline Level 8 (Year IV, Semester 2) & 77 & 23.1 & 43 & 22.8 & 34 & 23.4 \\
\hline \multicolumn{7}{|l|}{ No. of siblings at home } \\
\hline No. siblings & 11 & 3.3 & 6 & 3.2 & 5 & 3.4 \\
\hline$<3$ & 99 & 29.6 & 55 & 29.1 & 44 & 30.3 \\
\hline $4-7$ & 187 & 56 & 106 & 56.1 & 81 & 55.9 \\
\hline$>7$ & 37 & 11.1 & 22 & 11.6 & 15 & 10.3 \\
\hline \multicolumn{7}{|l|}{$\begin{array}{l}\text { Family monthly income } \\
\text { (1 USD = approx. } 3.77 \text { SR) }\end{array}$} \\
\hline Less than $2500 \mathrm{SR}$ & 16 & 4.8 & 10 & 5.3 & 6 & 4.1 \\
\hline $2500-5000 \mathrm{SR}$ & 31 & 9.3 & 18 & 9.5 & 13 & 9.0 \\
\hline $5000-10,000$ SR & 73 & 21.9 & 38 & 20.1 & 35 & 24.1 \\
\hline More than $10,000 \mathrm{SR}$ & 214 & 64.1 & 123 & 65.1 & 91 & 62.8 \\
\hline \multicolumn{7}{|l|}{ Do you drink coffee or tea? } \\
\hline Yes & 309 & 92.5 & 171 & 90.5 & 138 & 95.2 \\
\hline No & 25 & 7.5 & 18 & 9.5 & 7 & 4.8 \\
\hline \multicolumn{7}{|l|}{$\begin{array}{l}\text { If yes, how many cups per day? } \\
\qquad(n=309)\end{array}$} \\
\hline Less than 2 Cups & 126 & 40.8 & 67 & 39.2 & 59 & 42.8 \\
\hline 2-5 Cups & 166 & 53.7 & 93 & 54.4 & 73 & 52.9 \\
\hline More than 5 Cups & 17 & 5.5 & 11 & 6.4 & 6 & 4.3 \\
\hline \multicolumn{7}{|c|}{$\begin{array}{l}\text { What sources of drinking water does } \\
\text { your family use? }\end{array}$} \\
\hline Tap water & 79 & 23.7 & 41 & 21.7 & 38 & 26.2 \\
\hline Bottled water & 200 & 59.9 & 114 & 60.3 & 86 & 59.3 \\
\hline Both & 55 & 16.5 & 34 & 18.0 & 21 & 14.5 \\
\hline \multicolumn{7}{|c|}{$\begin{array}{c}\text { Do you hear about } H \text {. pylori infection } \\
\text { (a microbe which causes } \\
\text { peptic ulcers)? }\end{array}$} \\
\hline Yes & 257 & 76.9 & 155 & 82.0 & 102 & 70.3 \\
\hline No & 77 & 23.1 & 34 & 18.0 & 43 & 29.7 \\
\hline
\end{tabular}


Table 1. Cont.

\begin{tabular}{|c|c|c|c|c|c|c|}
\hline \multirow{2}{*}{ Items } & \multicolumn{2}{|c|}{$\begin{array}{l}\text { Total Sample } \\
\quad(n=334)\end{array}$} & \multicolumn{2}{|c|}{$\begin{array}{l}\text { Health Science } \\
\quad(n=189)\end{array}$} & \multicolumn{2}{|c|}{$\begin{array}{c}\text { Non-Health Science } \\
\quad(n=145)\end{array}$} \\
\hline & $n$ & $\%$ & $n$ & $\%$ & $n$ & $\%$ \\
\hline \multicolumn{7}{|c|}{$\begin{array}{l}\text { If yes, what is the source of your } \\
\text { knowledge? }(n=257)^{*}\end{array}$} \\
\hline Not applicable & 20 & 7.8 & 12 & 7.7 & 8 & 7.8 \\
\hline Family & 99 & 38.5 & 55 & 35.5 & 44 & 43.1 \\
\hline Mass media & 106 & 41.2 & 62 & 40.0 & 44 & 43.1 \\
\hline Reading articles & 160 & 62.3 & 100 & 64.5 & 60 & 58.8 \\
\hline Neighborhood & 13 & 5.1 & 9 & 5.8 & 4 & 3.9 \\
\hline \multicolumn{7}{|c|}{$\begin{array}{c}\text { Did you have previous history of } \\
\text { H. pylori infection? }\end{array}$} \\
\hline Yes & 60 & 18.0 & 32 & 16.9 & 28 & 19.3 \\
\hline No & 274 & 82.0 & 157 & 83.1 & 117 & 80.7 \\
\hline \multicolumn{7}{|c|}{ If yes, have you been treated? $(n=60)$} \\
\hline Yes & 54 & 90.0 & 27 & 84.4 & 27 & 96.4 \\
\hline No & 6 & 10.0 & 5 & 15.6 & 1 & 3.6 \\
\hline
\end{tabular}

* More than one response.

3.2. Comparison of Knowledge about H. pylori between Health Science and Non-Health Science Students

The overall knowledge scores of health science and non-health science students about H. pylori infection were low, indicating poor knowledge levels in both groups. A slightly larger percentage $(57.1 \%)$ of the health science students had poor knowledge compared to the non-health science students (52.4\%). Furthermore, less than $10 \%$ of the students in both groups had good knowledge about $H$. pylori (Figure 1).

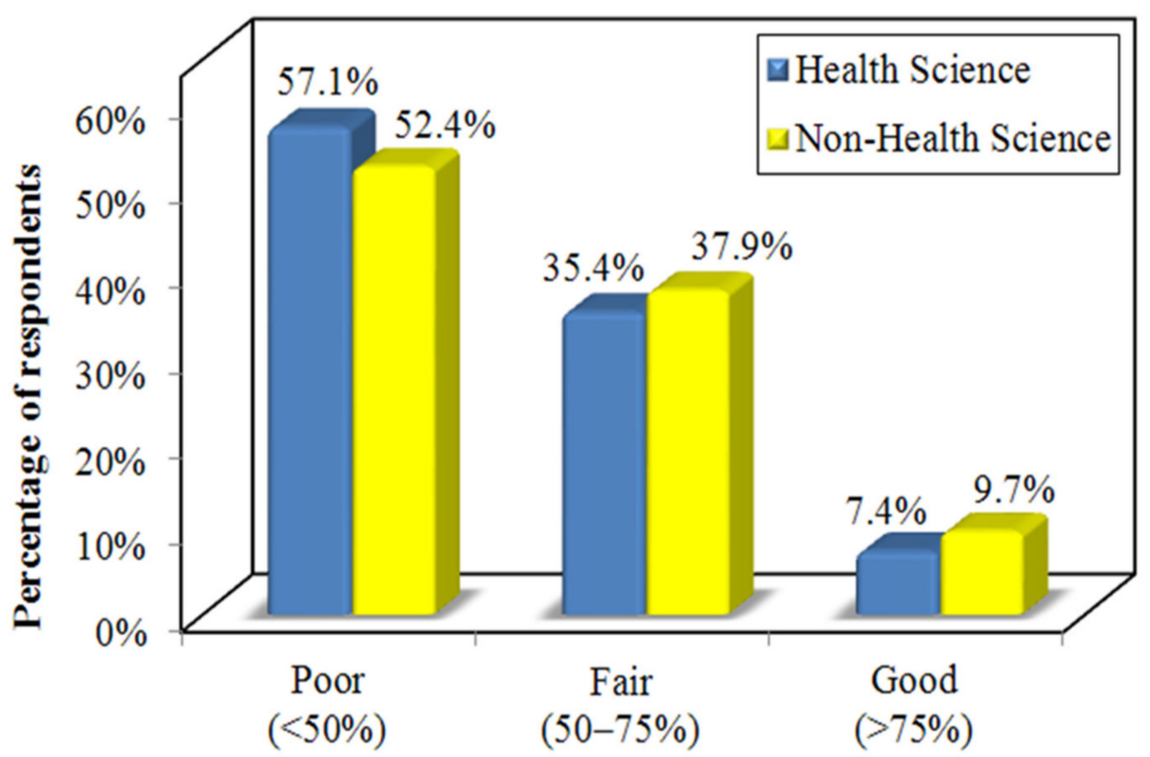

Figure 1. Bar graph showing the comparison of the level of knowledge scores among the health science and non-health science students.

The highest mean was recorded among both groups in the item "Helicobacter Pylori (H. pylori) commonly found in the stomach is a bacterium" ( 0.71 in health science and 0.72 in non-health science groups). In contrast, the lowest mean score was recorded in both groups on the item related to the diagnosis of $H$. pylori infection. Only $24.9 \%$ in the health science group and $30.3 \%$ in the non-health science group responded correctly that a breath test was used to diagnose $H$. pylori infection, recording a mean of 0.25 and 0.30 , respectively. 
The comparison of the overall mean between the health science (44.44) and non-health science students (46.75) showed no significant difference $(p=0.361)$. Further, there was no significant difference between the groups on all items, except one: "Which of the following is true regarding H. pylori infection?" (Correct response: some people with the infection do not experience any signs and symptoms). The non-health science students had a higher mean score (0.42) on this item than the health science students $(0.30)$. The difference was significant $(p=0.024)$, (Table 2$)$.

Table 2. Knowledge of the respondents about H. pylori infection items $(n=334)$.

\begin{tabular}{|c|c|c|c|c|c|c|c|c|c|}
\hline \multirow{3}{*}{ Questions/Items } & \multicolumn{4}{|c|}{$\begin{array}{l}\text { Health Science } \\
\quad(n=189)\end{array}$} & \multicolumn{4}{|c|}{$\begin{array}{l}\text { Non-Health Science } \\
\qquad(n=145)\end{array}$} & \multirow{3}{*}{$p$} \\
\hline & \multicolumn{2}{|c|}{ Incorrect } & \multicolumn{2}{|c|}{ Correct } & \multicolumn{2}{|c|}{ Incorrect } & \multicolumn{2}{|c|}{ Correct } & \\
\hline & $n$ & $\%$ & $n$ & $\%$ & $n$ & $\%$ & $n$ & $\%$ & \\
\hline $\begin{array}{l}\text { 1. Helicobacter Pylori (H. pylori) commonly } \\
\text { found in the stomach is a } \\
\text { (Bacterium) }\end{array}$ & 54 & 28.6 & 135 & 71.4 & 41 & 28.3 & 104 & 71.7 & 0.953 \\
\hline $\begin{array}{l}\text { 2. Which of the following is a } \\
\text { sign/symptom of } H \text {. pylori infection? } \\
\text { (Burning pain in the upper abdomen) }\end{array}$ & 86 & 45.5 & 103 & 54.5 & 60 & 41.4 & 85 & 58.6 & 0.452 \\
\hline $\begin{array}{l}\text { 3. A person suffering from } H \text {. pylori } \\
\text { infection will experience which of the } \\
\text { following? (Nausea) }\end{array}$ & 100 & 52.9 & 89 & 47.1 & 88 & 60.7 & 57 & 39.3 & 0.156 \\
\hline $\begin{array}{l}\text { 4. Which of the following is a risk factor } \\
\text { for } H \text {. pylori infection? } \\
\text { (Low socio-economic status) }\end{array}$ & 130 & 68.8 & 59 & 31.2 & 93 & 64.1 & 52 & 35.9 & 0.372 \\
\hline $\begin{array}{l}\text { 5. Which of the following is NOT a risk } \\
\text { factor for H. pylori infection? } \\
\text { (Eating plenty of chilly and pepper) }\end{array}$ & 108 & 57.1 & 81 & 42.9 & 78 & 53.8 & 67 & 46.2 & 0.542 \\
\hline $\begin{array}{l}\text { 6. H. pylori infection can be passed from } \\
\text { one person to another through which of the } \\
\text { following ways/routes? (Oral route) }\end{array}$ & 109 & 57.7 & 80 & 42.3 & 74 & 51.0 & 71 & 49.0 & 0.228 \\
\hline $\begin{array}{l}\text { 7. H. pylori can be diagnosed by } \\
\text { examination of (Breath test) }\end{array}$ & 142 & 75.1 & 47 & 24.9 & 101 & 69.7 & 44 & 30.3 & 0.266 \\
\hline $\begin{array}{l}\text { 8. Which of the following is a measure to } \\
\text { prevent H. pylori infection? } \\
\text { (Washing hands) }\end{array}$ & 91 & 48.1 & 98 & 51.9 & 75 & 51.7 & 70 & 48.3 & 0.518 \\
\hline $\begin{array}{l}\text { 9. If a person has } H . \text { pylori infection, } \\
\text { he/she can be treated with (tablets) }\end{array}$ & 98 & 51.9 & 91 & 48.1 & 76 & 52.4 & 69 & 47.6 & 0.919 \\
\hline $\begin{array}{l}\text { 10. The duration of treatment for H. pylori } \\
\text { infection is (one to two weeks) }\end{array}$ & 126 & 66.7 & 63 & 33.3 & 95 & 65.5 & 50 & 34.5 & 0.826 \\
\hline $\begin{array}{l}\text { 11. In order to avoid the recurrence of } H \text {. } \\
\text { pylori infection, a person should (comply } \\
\text { with the treatment plan) }\end{array}$ & 84 & 44.4 & 105 & 55.6 & 63 & 43.4 & 82 & 56.6 & 0.856 \\
\hline $\begin{array}{l}\text { 12. If your friend or relative is suspected } \\
\text { of having } H \text {. pylori infection, he/she should } \\
\text { seek immediate medical advice in which of } \\
\text { the following conditions? } \\
\text { (Persistent burning pain in the upper } \\
\text { abdomen) }\end{array}$ & 94 & 49.7 & 95 & 50.3 & 61 & 42.1 & 84 & 57.9 & 0.164 \\
\hline $\begin{array}{l}\text { 13. Which of the following is true } \\
\text { regarding H. pylori infection? } \\
\text { (Some people with the infection do not } \\
\text { experience any signs and symptoms) }\end{array}$ & 132 & 69.8 & 57 & 30.2 & 84 & 57.9 & 61 & 42.1 & 0.024 * \\
\hline $\begin{array}{l}\text { 14. What complication does H. pylori } \\
\text { infection cause? (Gastric cancer) }\end{array}$ & 116 & 61.4 & 73 & 38.6 & 92 & 63.4 & 53 & 36.6 & 0.699 \\
\hline Overall Mean & & & & & & & & & 0.361 \\
\hline
\end{tabular}




\subsection{Factors Accociated with the Knowledge about H. pylori among Respondents}

Table 3 shows that the level of knowledge of the respondents was significantly associated with their university level $\left(\chi^{2}=39.939, p<0.001\right)$, family monthly income $\left(\chi^{2}=17.658\right.$, $p<0.007)$, having heard about H. pylori infection $\left(\chi^{2}=19.675, p<000.1\right)$, and a previous history of $H$. pylori infection $\left(\chi^{2}=20.116, p<000.1\right)$. Knowledge on $H$. pylori was independent of all other socio-demographic characteristics of the students, including the field of study (health science and non-health science).

Table 3. Relationship between the socio-demographic characteristics and the knowledge of the respondents about $H$. pylori infection $(n=334)$.

\begin{tabular}{|c|c|c|c|c|c|c|c|c|}
\hline \multirow{3}{*}{$\mathbf{Q}$} & \multirow{3}{*}{ Socio Demographic Data } & \multicolumn{6}{|c|}{ Knowledge about $H$. pylori Infection } & \multirow{3}{*}{$p$} \\
\hline & & \multicolumn{2}{|c|}{$\begin{array}{c}\text { Poor }<50 \% \\
(n=184)\end{array}$} & \multicolumn{2}{|c|}{$\begin{array}{l}\text { Fair } 50-75 \% \\
\quad(n=122)\end{array}$} & \multicolumn{2}{|c|}{$\begin{array}{l}\text { Good } \geq 75 \% \\
\quad(n=28)\end{array}$} & \\
\hline & & No. & $\%$ & No. & $\%$ & No. & $\%$ & \\
\hline \multirow[t]{4}{*}{1} & Age (Years) & & & & & & & \\
\hline & $<20$ & 52 & 55.3 & 32 & 34.0 & 10 & 10.6 & \\
\hline & $20-<30$ & 116 & 55.0 & 79 & 37.4 & 16 & 7.6 & 0.905 \\
\hline & $\geq 30$ & 16 & 55.2 & 11 & 37.9 & 2 & 6.9 & \\
\hline \multirow[t]{3}{*}{2} & Gender & & & & & & & \\
\hline & Male & 84 & 56.8 & 57 & 38.5 & 7 & 4.7 & \\
\hline & Female & 100 & 53.8 & 65 & 34.9 & 21 & 11.3 & 0.098 \\
\hline \multirow[t]{5}{*}{3} & Field of study in the university & & & & & & & \\
\hline & Applied Medical Sciences & 76 & 57.6 & 50 & 37.9 & 6 & 4.5 & \\
\hline & Nursing & 32 & 56.1 & 17 & 29.8 & 8 & 14.0 & \\
\hline & Sciences & 40 & 50.0 & 34 & 42.5 & 6 & 7.5 & 0.227 \\
\hline & Computer Sciences & 36 & 55.4 & 21 & 32.3 & 8 & 12.3 & \\
\hline \multirow[t]{6}{*}{4} & University level & & & & & & & \\
\hline & Level 4 (Year II, Semester 2) & 103 & 70.1 & 39 & 26.5 & 5 & 3.4 & \\
\hline & Level 5 (Year III, Semester 1) & 20 & 52.6 & 17 & 44.7 & 1 & 2.6 & \\
\hline & Level 6 (Year III, Semester 2) & 28 & 56.0 & 17 & 34.0 & 5 & 10.0 & $<0.001^{*}$ \\
\hline & Level 7 (Year IV, Semester 1) & 9 & 40.9 & 9 & 40.9 & 4 & 18.2 & \\
\hline & Level 8 (Year IV, Semester 2) & 24 & 31.2 & 40 & 51.9 & 13 & 16.9 & \\
\hline \multirow[t]{5}{*}{5} & No. of siblings at home & & & & & & & \\
\hline & No. siblings & 7 & 3.8 & 3 & 2.5 & 1 & 3.6 & \\
\hline & $<3$ & 52 & 28.3 & 39 & 32.0 & 8 & 28.6 & \\
\hline & $4-7$ & 106 & 57.6 & 65 & 53.3 & 16 & 57.1 & 0.964 \\
\hline & $>7$ & 19 & 10.3 & 15 & 12.3 & 3 & 10.7 & \\
\hline \multirow[t]{5}{*}{6} & $\begin{array}{l}\text { Family monthly income }(1 \mathrm{USD}=\text { approx. } \\
\qquad 3.77 \mathrm{SR})\end{array}$ & & & & & & & \\
\hline & Less than 2500 SR & 11 & 68.8 & 2 & 12.5 & 3 & 18.8 & \\
\hline & 2500-5000 SR & 24 & 77.4 & 6 & 19.4 & 1 & 3.2 & \\
\hline & $5000-10,000$ SR & 46 & 63.0 & 22 & 30.1 & 5 & 6.8 & $0.007^{*}$ \\
\hline & More than 10,000 SR & 103 & 48.1 & 92 & 43.0 & 19 & 8.9 & \\
\hline \multirow[t]{3}{*}{10} & $\begin{array}{l}\text { Have you hear about } H \text {. pylori infection } \\
\text { (a microbe that causes peptic ulcers?) }\end{array}$ & & & & & & & \\
\hline & Yes & 126 & 49.0 & 103 & 40.1 & 28 & 10.9 & \\
\hline & No & 58 & 75.3 & 19 & 24.7 & 0 & 0.0 & $<0.001^{*}$ \\
\hline \multirow[t]{3}{*}{12} & $\begin{array}{c}\text { Do you have previous history of } H . \text { pylori } \\
\text { infection? }\end{array}$ & & & & & & & \\
\hline & Yes & 20 & 33.3 & 28 & 46.7 & 12 & 20.0 & \\
\hline & No & 164 & 59.9 & 94 & 34.3 & 16 & 5.8 & $<0.001$ \\
\hline
\end{tabular}




\section{Discussion}

This descriptive cross-sectional study compared the knowledge of $H$. pylori between health science and non-health science undergraduate students in Saudi Arabia and found that the overall level of knowledge was poor among both groups. Our finding of poor knowledge was similar to those reported among physicians and students in a national survey in China [22] and among the healthy population in Korea [24]. A lower level of knowledge (24.6\%) was also reported among the general population in the United Arab Emirates (UAE) [25]. In our study, the largest proportion of students were in the younger age group (20-30 years) studying in health science colleges (56.6\%), in the fourth level of their program $(44 \%)$, and female students $(55.7 \%)$. The variations in the respondents' characteristics in this study and those in the Chinese, Korean, and UAE studies may explain the possible reasons for the differences in the knowledge level.

The current study also found a slightly higher level of knowledge $(M=46.75)$ in the non-health science students on $H$. pylori infection, compared to the health science students $(\mathrm{M}=44.44)$; the difference was not significant $(0.361)$. The apparently higher knowledge in the non-health science students could be attributed to the fact that a section of them had undergone courses in Zoology, Microbiology, Physiology, and Bacteriology. It is possible that these students may have been exposed to some information on H. pylori infection, thereby influencing their knowledge scores. This may also explain why health science students recorded a significantly lower mean score in one item $(p=0.024)$ "Which of the following is true regarding $H$. pylori infection?" to which students responded correctly that some people with the infection do not experience any signs and symptoms. Furthermore, a low emphasis on $H$. pylori infection in the curriculum of health science students may explain the difference. This study found that, overall, students recorded the highest mean (0.71) for the item "H. pylori is commonly found in the stomach is a bacterium" and the least mean (0.25) on the item " $H$. pylori can be diagnosed by examination of breath test". The findings suggest that students know that $H$. pylori is a disease related to the gastrointestinal system. Nevertheless, they had limited awareness of how the condition is diagnosed. Similarly, a lack of knowledge regarding diagnostic and treatment recommendations for H. pylori was also recorded in a study by Cano-Contreras et al. [26] among primary care physicians in Mexico. It is therefore not surprising that our respondents had a low level of knowledge regarding diagnosis. Future educational interventions should focus on this aspect of $H$. pylori awareness.

A lower level of knowledge ranging from $23.8-31.1 \%$ was recorded in Chinese and Korean communities regarding the route of $H$. pylori transmission [20,21,24], compared to the undergraduate health science $(42.3 \%)$ and non-health science $(49 \%)$ students in the current study. The low level of education (high school level to high school graduate) in the Chinese and Korean population, compared to the respondents in our study who are university students, may explain the reason for the differences.

With regards to symptoms and complications of H. pylori infection, Shin et al. [24] reported correct responses on knowledge items on symptoms in $37.2 \%$ and complications in $58.3 \%$ of healthy Korean adults. These figures are lower than our findings that recorded correct response in two items of symptoms $47.1 \%$ and $54.5 \%$ of health science and in $39.3 \%$ and $58.6 \%$ of non-health science students. Regarding complications, correct responses were found in $38.6 \%$ health science and $36.6 \%$ non-health science students.

Interestingly, the university level was significantly associated with the respondents' knowledge level about $H$. pylori infection. A previous study among the general population in Cameroon also showed a significant association between level of education and knowledge on $H$. pylori infection among participants. However, most of them had tertiary education and only $20.9 \%$ among them had a low level of knowledge on H. pylori [27]. Similarly, in the present study, a low proportion of students (31.2\%) who had progressed to the fourth year (in level 8) had poor knowledge compared to the large proportion (70.1\%) in the second year (level 2) of study, suggesting that they have acquired knowledge on H. pylori with advancement in educational levels. Moreover, the level of education was 
associated with knowledge on $H$. pylori infection among the general population who were screened in Cameroon [27].

Concerning family monthly income, a significant association was found with the level of knowledge on H. pylori infection. Most of the respondents (64.1\%) in this study were from Class 3 or a high socioeconomic status (family income $>10,000 \mathrm{SR} ; 1 \mathrm{USD}=3.77 \mathrm{SR}$ ). A family in Saudi Arabia earning between 10,000 to 15,000 SR belongs to Class 3 socioeconomic status; the highest being Class 4 (above 15,000 SR) [28]. In parallel, a study in China showed that people with medium to low levels of family income have poor knowledge regarding $H$. pylori, besides having a high infection rate [21].

This study also found a significant association between the item that assessed whether the students had heard about H. pylori, and their knowledge level. Undeniably, H. pylori infection is highly prevalent in developing countries whereas in Saudi Arabia it is hyperendemic [29]. The Ministry of Health in Saudi Arabia has an electronic media interface that publishes information on health issues through the awareness platform, which is accessible to the public, including students. Furthermore, a large proportion of our respondents reported "reading articles" and "media" as their main sources of information. This may explain why most of the students $(76.9 \%)$ reported having heard about $H$. pylori, which is a higher proportion than those reported among Chinese physicians and the general population (49.8\%) [22] and those reported in a review of nine studies from China, South Korea, North America, Ethiopia, India, and Malaysia (22-33\%). Eight of the nine studies were conducted among the population at risk, except North America, where they were from the general population. Variations in the population characteristics may also account for the differences between our findings and those of previous studies [30].

The respondents' previous history of $H$. pylori infection was significantly associated with their knowledge levels. Often, people have limited knowledge of the nature of the disease and its complications [31]. However, the experience of an illness may have an influence on their knowledge through interactions with health personnel, especially when they undergo treatment. In total, $90 \%$ (54 out of 60 ) had undergone treatment for $\mathrm{H}$. pylori infection and may have acquired knowledge during their treatment. This study did not find an association between all other socio-demographic factors (age, gender, number of siblings), including the field of university study (health science versus non-health science) and knowledge of $H$. pylori, suggesting that these factors are independent of H. pylori knowledge among university students. Future studies should explore these factors in larger samples.

\section{Strengths and Limitations}

The strength of this study is that it is the first to compare the knowledge of health science and non-health science university students about H. pylori in Saudi Arabia. However, this study is not without limitations. Participation in the online survey was voluntary. Hence most of the participants may have been interested in the subject, leading to sampling bias. The study was conducted in one university, therefore limiting the generalizability of the findings. Previous studies [20,21,32,33] found that handwashing practices before eating a meal and after using the toilet, safe food practices, and drinking water from a clean source were associated with less $H$. pylori infection. Knowledge on these aspects was not assessed in the current study. Further, assessing classroom or school education as a source of $H$. pylori information would provide evidence on whether students had acquired knowledge about $H$. pylori infection before embarking on their university education. Future studies should consider including these aspects to explore sources of information. We assessed the students' knowledge using a 14-item questionnaire developed by the authors. Using this survey, a small percentage of students who had responded "No" to the item "Have you hear about $H$. pylori infection (a microbe which causes peptic ulcers?)" provided responses to other knowledge items in the questionnaire. Although the questionnaire was validated and the reliability established, we attribute the response of the item to the chance factor in survey studies. 


\section{Conclusions}

Saudi undergraduate students have relatively low knowledge about $H$. pylori, particularly among health science and non-health science students. Low H. pylori knowledge has been reported globally. Future studies on larger samples and varied populations will be of significant value to identify knowledge gaps. Raising health awareness regarding H. pylori infection is essential for effectively implementing population-based $H$. pylori screening and treatment programs. Moreover, interventions, including health awareness educational programs, would increase adherence to advice to seek medical attention. The findings of this study will form the basis for developing educational programs.

Author Contributions: T.A.H. theorized and designed the study, reviewed the literature, acquired the data, and critically commented and wrote the original draft of the manuscript. J.L.D. contributed to the conceptualization and design of the study, interpreted the results, wrote the manuscript and did critical revision, and edited the final version of the manuscript. S.Z. contributed to the study design, managed data collection, and analyzed the results. R.B.T. contributed to the study design, interpreted the results, and edited the final version of the manuscript. M.L.V.D. contributed to the design and discussion of the study. M.A.M. contributed to the study design, managed data collection, and interpreted the results. All authors have read and agreed to the published version of the manuscript.

Funding: This research received no external funding.

Institutional Review Board Statement: The study was conducted according to the guidelines of the Declaration of Helsinki, and approved by the Institutional Review Board of King Saud University (Protocol code: 21/0111/IRB).

Informed Consent Statement: Participation in the online survey, implied consent for the study.

Acknowledgments: The authors would like to thank the Deanship of Scientific Research, College of Applied Medical Sciences Research Center, King Saud University, for funding this research and the Researchers Support and Services Unit for their technical support. Appreciation is also expressed to Mustafa Bodrick, Adjunct Faculty at King Saud University, Saudi Arabia, and at Johns Hopkins University, USA for the final language editing and proofreading of this manuscript.

Conflicts of Interest: All authors declare that they have no competing interests.

\section{References}

1. Sjomina, O.; Pavlova, J.; Niv, Y.; Leja, M. Epidemiology of Helicobacter pylori infection. Helicobacter 2018, 23, e12514. [CrossRef] [PubMed]

2. Eusebi, L.H.; Zagari, R.M.; Bazzoli, F. Epidemiology of Helicobacter pylori Infection. Helicobacter 2014, 19, 1-5. [CrossRef] [PubMed]

3. Alghamdi, T.S.; Ansari, T.; Bashir, A.A.; Batais, M.A.; Aldhahi, M.F.; Alanazi, M.A. Helicobacter Pylori infection among dyspepsia patients in suburbs of Riyadh, Saudi Arabia. J. Pak. Med. Assoc. 2020, 70, 2174-2177. [PubMed]

4. Alsulaimany, F.A.S.; Awan, Z.A.; Almohamady, A.M.; Koumu, M.I.; Yaghmoor, B.E.; Elhady, S.S.; Elfaky, M.A. Prevalence of Helicobacter pylori Infection and Diagnostic Methods in the Middle East and North Africa Region. Medicina-Lithuania 2020, 56, 15. [CrossRef]

5. Plummer, M.; Franceschi, S.; Vignat, J.; Forman, D.; de Martel, C. Global burden of gastric cancer attributable to Helicobacter pylori. Int. J. Cancer 2015, 136, 487-490. [CrossRef] [PubMed]

6. Bray, F.; Ferlay, J.; Soerjomataram, I.; Siegel, R.L.; Torre, L.A.; Jemal, A. Global cancer statistics 2018: GLOBOCAN estimates of incidence and mortality worldwide for 36 cancers in 185 countries. Cancer J. Clin. 2018, 68, 394-424. [CrossRef]

7. Urita, Y.; Watanabe, T.; Kawagoe, N.; Takemoto, I.; Tanaka, H.; Kijima, S.; Kido, H.; Maeda, T.; Sugasawa, Y.; Miyazaki, T.; et al. Role of infected grandmothers in transmission of Helicobacter pylori to children in a Japanese rural town. J. Paediatr. Child. Health 2013, 49, 394-398. [CrossRef]

8. Leja, M.; Grinberga-Derica, I.; Bilgilier, C.; Steininger, C. Review: Epidemiology of Helicobacter pylori infection. Helicobacter 2019, 24, e12635. [CrossRef]

9. Malfertheiner, P.; Megraud, F.; O’Morain, C.A.; Gisbert, J.P.; Kuipers, E.J.; Axon, A.T.; Bazzoli, F.; Gasbarrini, A.; Atherton, J.; Graham, D.Y.; et al. Management of Helicobacter pylori infection-the Maastricht V/Florence Consensus Report. Gut 2017, 66, 6-30. [CrossRef]

10. Correa, P.; Piazuelo, M.B. Natural history of Helicobacter pylori infection. Dig. Liver Dis. 2008, 40, 490-496. [CrossRef] 
11. Bui, D.; Harris, R.B.; Oren, E.; Brown, H. Serologic Evidence for Fecal-Oral Transmission of Helicobacter pylori. Am. J. Trop. Med. Hyg. 2016, 94, 82-88. [CrossRef]

12. Genta, R.M.; Turner, K.O.; Sonnenberg, A. Demographic and socioeconomic influences on Helicobacter pylori gastritis and its pre-neoplastic lesions amongst US residents. Aliment Pharmacol Ther. 2017, 46, 322-330. [CrossRef] [PubMed]

13. Attila, T.; Zeybel, M.; Yigit, Y.E.; Baran, B.; Ahishali, E.; Alper, E.; Aslan, F.; Ergonul, O.; Mungan, Z. Upper socioeconomic status is associated with lower Helicobacter pylori infection rate among patients undergoing gastroscopy. J. Infect. Dev. Ctries. 2020, 14, 298-303. [CrossRef]

14. Zhang, F.H.; Pu, K.; Wu, Z.Q.; Zhang, Z.Y.; Liu, X.; Chen, Z.F.; Ye, Y.W.; Wang, Y.P.; Zheng, Y.; Zhang, J.H.; et al. Prevalence and associated risk factors of Helicobacter pylori infection in the Wuwei cohort of north-western China. Trop. Med. Int. Health 2020, 26, 290-300. [CrossRef]

15. Amaral, O.; Fernandes, I.; Veiga, N.; Pereira, C.; Chaves, C.; Nelas, P.; Silva, D. Living Conditions and Helicobacter pylori in Adults. BioMed. Res. Int. 2017, 2017, 1-5. [CrossRef] [PubMed]

16. Serra, M.A.A.d.O.; Lima, V.P.; Santos, C.A.A.S.D.; de Araujo, M.F.M. Helicobacter Pylori cagA+ Genotype is Associated With Consumption of Untreated Drinking Water in North-Eastern Brazil. Biol. Res. Nurs. 2020, 22, 544-551. [CrossRef]

17. Wu, W.; Leja, M.; Tsukanov, V.; Basharat, Z.; Hua, D.; Hong, W. Sex differences in the relationship among alcohol, smoking, and Helicobacter pylori infection in asymptomatic individuals. J. Int. Med Res. 2020, 48. [CrossRef] [PubMed]

18. Wynne, A.; Hastings, E.V.; Colquhoun, A.; Chang, H.J.; Goodman, K.J.; Grp, C.A.W. Untreated water and Helicobacter pylori: Perceptions and behaviors in a Northern Canadian community. Int. J. Circumpolar Health 2013, 72, $704-705$.

19. Novelli, P. Knowledge about causes of peptic ulcer disease. J. Am. Med. Assoc. 1997, 278, 1731.

20. Chen, S.-Y.; Liu, T.-S.; Fan, X.-M.; Dong, L.; Fang, G.-T.; Tu, C.-T.; Gu, X.-Y.; Wang, J.-Y. Epidemiological study of Helicobacter pylori infection and its risk factors in Shanghai. Zhonghua Yi Xue Za Zhi 2005, 85, 802-806.

21. Xia, P.; Ma, M.-F.; Wang, W. Status of Helicobacter pylori infection among migrant workers in Shijiazhuang, China. Asian Pac. J. Cancer Prev. 2012, 13, 1167-1170. [CrossRef]

22. Wu, Y.; Su, T.; Zhou, X.; Lu, N.; Li, Z.; Du, Y. Awareness and attitudes regarding Helicobacter pylori infection in Chinese physicians and public population: A national cross-sectional survey. Helicobacter 2020, 25, e12705. [CrossRef]

23. Oh, D.-Y.; Choi, K.S.; Shin, H.-R.; Bang, Y.-J. Public Awareness of Gastric Cancer Risk Factors and Disease Screening in a High Risk Region: A Population-Based Study. Cancer Res. Treat. 2009, 41, 59-66. [CrossRef]

24. Shin, D.W.; Cho, J.; Kim, S.H.; Kim, Y.J.; Choi, H.C.; Son, K.Y.; Park, S.M.; Park, J.H.; Park, M.S.; Cho, B. Preferences for the "screen and treat" Strategy ofHelicobacter pylori toPrevent Gastric Cancer in Healthy Korean Populations. Helicobacter 2013, 18, 262-269. [CrossRef]

25. Malek, A.; Al Khaldi, M.; Odeh, L.; Tariq, A.; Al Fardan, M.; Barqawi, H. Knowledge and Attitude towards Helicobacter pylori: Awareness about Health Impacts of H. pylori Gastric Ulcer and Its Carcinogenic Potential among Adults in Sharjah. Int. J. Med. Health Sci. 2017, 11, 1.

26. Cano-Contreras, A.D.; Rascon, O.; Amieva-Balmori, M.; Rios-Galvez, S.; Maza, Y.J.; Meixueiro-Daza, A.; Roesch-Dietlen, F.; Remes-Troche, J.M. Approach, attitudes, and knowledge of general practitioners in relation to Helicobacter pylori is inadequate. There is much room for improvement! Rev. Gastroenterol. Mex. 2018, 83, 16-24. [CrossRef]

27. Abongwa, L.E.; Samje, M.; Antoine, K.S.; Alberic, S.; Elvis, M.; Benardette, L.; Kuchonde, P.; Roland, F. Knowledge, Practice and Prevalence of Helicobacter Pylori Infection in the North West Region of Cameroon. Clin. Biotech. Microbiol. 2017, 1, 135-143.

28. Khan, S.A.; Alsiny, F.; Makki, A.; Ali, A.; Alansari, I.; Khan, S. Socioeconomic status dependent medical complexities in children with sickle cell disease in Saudi Arabia. Saudi J. Biol. Sci. 2020, 27, 1781-1787. [CrossRef] [PubMed]

29. Alharbi, R.H.; Ghoraba, M. Prevalence and patient characteristics of Helicobacter pylori among adult in primary health care of security forces hospital Riyadh, Saudi Arabia, 2018. J. Fam. Med. Prim. Care 2019, 8, 2202-2206. [CrossRef] [PubMed]

30. Driscoll, L.J.; Brown, H.; Harris, R.B.; Oren, E. Population Knowledge, Attitude, and Practice Regarding Helicobacter pylori Transmission and Outcomes: A Literature Review. Front. Public Health 2017, 5. [CrossRef] [PubMed]

31. Liu, Q.; Zeng, X.; Wang, W.; Huang, R.-L.; Huang, Y.-J.; Liu, S.; Huang, Y.-H.; Wang, Y.-X.; Fang, Q.-H.; He, G.; et al. Awareness of risk factors and warning symptoms and attitude towards gastric cancer screening among the general public in China: $\mathrm{A}$ cross-sectional study. BMJ Open 2019, 9, e029638. [CrossRef] [PubMed]

32. Lee, Y.Y.; Ismail, A.W.; Mustaffa, N.; Musa, K.I.; Majid, N.A.; Choo, K.E.; Raj, S.M.; Derakhshan, M.H.; Malaty, H.M.; Graham, D.Y. Sociocultural and Dietary Practices Among Malay Subjects in the North-Eastern Region of Peninsular Malaysia: A Region of Low Prevalence of Helicobacter pylori Infection. Helicobacter 2012, 17, 54-61. [CrossRef] [PubMed]

33. Abebaw, W.; Kibret, M.; Abera, B. Prevalence and Risk Factors of H. pylori from Dyspeptic Patients in Northwest Ethiopia: A Hospital Based Cross-sectional Study. Asian Pac. J. Cancer Prev. 2014, 15, 4459-4463. [CrossRef] [PubMed] 